\title{
Grierson's ghost never dies: The Fiji Film Unit 1970-1985
}

\section{ABSTRACT}

This article explores what happens when a documentary film form developed within a specific social, ideological, institutional, and aesthetic context-namely, the so-called British Documentary Movement, under the aegis of John Grierson-is deployed in very different cultural spaces: the colonial and post-colonial. There are several layers of argument involved, but I will pursue only one of them in the space available here. At a kind of metatheoretical level, it is arguable that Indigenous and Asian cultures are inimical to core values of the Western documentary project: in particular, to the belief in, and rhetorical power of, the material, historical word. In these societies, what might be called 'spiritual' or 'other' worlds have as much everyday reality as Griersonian 'actuality'.

\section{PHILIP ROBERTSON \\ Central Queensland University}

$\mathrm{T}$

THIS ARTICLE explores what happens when a documentary film form developed within a specific social, ideological, institutional, and aesunder the aegis of John Grierson - is deployed in very different cultural spaces: the colonial and post-colonial. There are several layers of argument involved, but I will pursue only one of them in the space available here. At a kind of metatheoretical level, it is arguable that Indigenous and Asian cultures are inimical to core values of the Western documentary project: in particular, to the belief in, and rhetorical power of, the material, historical word. In these societies, what might be called 'spiritual' or 'other' worlds have as much everyday reality as Griersonian 'actuality'. But this is a story for another time and place. ${ }^{1}$ 
Another level of argument concerns the nature of documentary itself, and I do not want to enter here into these ongoing debates about definitions and styles of documentary, nor attempt to distinguish documentary from either propaganda or journalism. But this much can be said: in Grierson's writings and work, there are three genres of documentary production, placed in a hierarchy of 'artistic' value.

Beyond the newsmen and the magazine men and the lecturers (comic or interesting or exciting or only rhetorical), one begins to wander into the world of documentary proper, into the only world in which documentary can hope to achieve the ordinary virtues of an art. (Grierson, 1946, p. 7)

At the top of the artistic scale, then, are prestige, art films (think Night Mail 1936, or Drifters 1929); at the bottom are what Grierson somewhat dismissively called 'educationals' - heavily voiced-over, didactic promulgation of Government messages on health, education, and other policy areasfilms not far removed from propaganda. Grierson was fond of quoting two dictums: 'I look on the cinema as a pulpit'; and, from Leon Trotsky via Dziga Vertov, 'It is as a hammer rather than a mirror that I have sought to use the medium' (Grierson 1946, pp. 12, 24). In the middle of Grierson's hierarchy, however, are more blurred, hybrid, in-between forms, such as newsreels, which are the subject of this study. All three genres are represented in every Film Unit seeded by Grierson around the British Empire.

For, as well as defining both an ideology and an aesthetic which was to dominate documentary for a generation, the British Documentary Movement also created an institutional structure which was readily reproduceable throughout the Commonwealth, under the guidance of Grierson himself in Canada (1939), New Zealand (1941) and Australia (1945) (Moran 1991: 135). For example, in 1958 it was extended to Hong Kong, when the Public Relations Officer, John Murray, submitted a confidential report to Government on his return from a London conference for British Foreign Service information officers. The Report argued for a greatly expanded and 'modernised' publicity apparatus and for the establishment of a government film-making capability:

Apart from prestige documentary films in colour, running time 15 to 20 minutes, of which we could with profit use at least one a year, the field 
for short news and magazine items to be used both in cinema newsreels and television programmes is practically unlimited ... [Television's] consumption is so voracious that almost any competently made news 'short' with reasonable story value is likely to secure acceptance. (Murray, 1958, pp. 7-8)

Here is an interesting aside: behind Murray's argument lay a fear that Hong Kong was falling behind other 'colonial territories' in terms of expenditure on publicity; in fact, lying third from the bottom in a list of 24 that included numerous African, Mediterranean and Caribbean possessions, as well as others closer to home such as 'Singapore, Malaya, Fiji and Brunei' (Murray 1958:, 2, and Appendix D). In a classic bureaucratic hedge, the report notes that: 'Comparisons are notoriously odious and can be misleading, but most colonies are spending much more on their information services' (Murray 1958: 2). Fiji, alas, was not among the big spenders, at least not then, and perhaps not even today.

\section{Grierson on documentary}

The argument I want to develop here deals primarily with the genre of 'short news or magazine items', although I will touch on that other form, 'prestige documentary films in colour'. My argument draws on post-colonial theory, suggesting that imperialism corrupts both coloniser and colonised, and that this process is revealed through film, literary, photographic, fine art, and other texts. In essence, slippages - false notes, strange hybridities, transmutations - occur which are inescapable in the transfer of a metropolitan art form to these colonial and postcolonial spaces. I explore such moments of disjunction, incongruity, contamination, anachronism, blurring, and breakdown of the documentary form through the early films of the Fiji Film Unit.

The founding of the Fiji Film Unit coincided with independence, in late 1970. Records are hazy for its first year, but it is probable that Rob Wright junior - who was the official Fiji Government Information Service photographer, and had some experience with the New Zealand Broadcasting Commission-ordered the equipment to set up a very basic $16 \mathrm{~mm}$ film production facility (what remains of this initial set-up is now rusting in the Government Buildings basement). What is known is that the first production of the new Unit - directed and shot by Wright, and edited by the Unit's first and only employee at the time, Chinese Fijian Jessie Leong — was a film about the 
royal visit associated with Independence activities and celebrations. Perhaps without realising it, the Fiji Film Unit thus came into being in the footsteps of a long and mostly honourable documentary tradition, and inaugurated itself through a classic strategic move: royal visits were staple fare for these Government Film Units set up around the Empire from around the early 1940s.

But it was the arrival in late 1971 of Alan Harkness, an Australian filmmaker of considerable and varied experience, that would set the production agenda, house style, organisational structure, and strategic mission for the Film Unit for the rest of the decade. The equipment Harkness found in place was, to all intents and purposes, identical to that used by Grierson in the 1930s: that is to say, although the main camera was $16 \mathrm{~mm}$ rather than $35 \mathrm{~mm}$, it was an unblimped Arriflex ST (supplemented by two wind-up Bell and Howells); a Nagra recorder was used to record 'wild' sound, but synchronised sound shooting was virtually impossible (there was a cumbersome blimp that could be attached to the Arri if necessary, but it was awkward and timeconsuming to mount and only deployed for important political speeches). Hence the films follow a strict Griersonian formula: a montage of silent 'actuality' images set to music, with a 'voice-of-God' commentary. Fiji Day 1971, celebrating the first anniversary of Independence, was Alan Harkness's first production for the Unit (and I can report that, more than 30 years later, he can still remember almost word for word the remarkable speech by Prime Minister Ratu Sir Kamisese Mara).

As far as I am aware, I am the first person to screen Fiji Day 1971 in more than 30 years; and delegates to the 2004 Journalism Education Association (JEA) conference were the first audience to see it since its initial release. But before exploring within the context of this film and the Fiji Film Unit as a whole the issues flagged in my introductory remarks, I want to jump back 75 years to that complex figure, John Grierson ('father of the British Documentary Movement'), whose unseen hand was so influential for the documentary film movement worldwide, but is particularly central to the whole concept, purpose, and ideology of an official, state-run film production apparatus.

His project needs to be situated in its particular historical context: it is a reformist, essentially conservative vision of the potential and need for rational (that is, non-violent) answers to class, national, and indeed, global divisions and conflicts, and a belief in the 'uplifting' power of education through the dissemination of 'true' information and facts - an ideological companion to the working-class Mechanics Institutes and Workers' Educational Associa- 
tions, in whose halls moreover the Movement's films were routinely screened. The Movement's retrospective claims to having put ordinary workers' faces (and working class voices) on the screen for the first time, and to having addressed contemporary social issues - as in, for example, Housing Problems (1935) - must be read in the context of Grierson's well-documented vision of national and imperial harmony at a time of crisis for both. In the depths of the Great Depression, this was a moment when recent memories of crippling general strikes and the Russian revolution itself held stark lessons for the ruling elites in Britain, and when even loyal former colonies like Australia threatened to default on the repayment of loans to London (I refer to the Jack Lang affair, a little-known pre-figuring of the contemporary Third World debt crisis: in the early 1930s the New South Wales Premier refused to remit scarce funds to London, in the face of urgent social needs at home, only to be dismissed by the colonial Governor of the day).

Grierson's vision, of course, is more sophisticated than that of an earlier generation's 19th century jingoism; as historian Stephen Constantine notes, Griersonian documentary for the Empire Marketing Board and the Crown Film Unit replaced military and colonialist symbolism with 'images of pastoral calm, harmonious trade, industrial and agricultural progress' (Constantine 1986: 218). Grierson himself remarks: 'Our command of peoples becomes solely a co-operative effort in the tilling of soil, the reaping of harvests, and the organisation of a world economy. For the old flags of exploitation it substitutes the new flags of common labour' (cited in Constantine 1986, pp. 217218). It is through the idea of 'common labour', reinforced by a biblical cadence in the passage quoted above, that Grierson's outward-looking imperial mission rejoins his didactic domestic project. His view of common labour betrays both its origins and its purpose; it is the perspective of an élite bourgeoisie charged with enacting a vision of social hierarchy and harmony in the face of threatening, centrifugal forces. Constantine paraphrases ironically: 'Beneficiaries of this [imperial] enterprise were the heroic figures of labour, Indian tea-pickers, Scottish shepherds, English industrial workers, Canadian lumbermen, North Sea fishermen' (Constantine, 1986, pp. 217); films presumably referenced by this quote include Drifters (1929), Song of Ceylon (1937), Night Mail (1936), and Industrial Britain (1933). Griersonian paeans to manual labour and industrial technologies at home and abroad deliberately elide, however, the real structures of the national and imperial economies, particularly their underlying relationships of capital and labour, and aestheticise 
social, colonial and workplace processes in ways that, for example, Walter Benjamin and Bertoldt Brecht well recognised in other contemporary artistic contexts - notably photography and the theatre. Indeed, firmly yoked to domestic national and imperial policies, what is remarkable about the Griersonian documentary project is the way it managed to appropriate the formal strategies of revolutionary Russian film-making to its own, élite bourgeois purposes (Constantine, 1986, pp. 209-210). Note that Grierson's first act in his long career was to build a small theatrette to screen Russian films, particularly the agit-prop work of Dziga Vertov and Joris Ivens.

It is these innovative formal claims of Griersonian documentary that have ensured the films' longevity and continuing critical interest. By any classic definition of propaganda - for example, 'information with not just a tendentious orientation but an institutional base (Paget, 1990, p. 20, original emphasis) - Griersonian documentary is a paradigm case. From a post-colonial perspective, however, standard formal distinctions between documentary, propaganda and film journalism are of little concern; they are too crude a filter for the more subtle cultural processes that interest us. Catch-phrases such as 'I look on the cinema as a pulpit' should not be taken at face value; Grierson believed in his heart that another order of truth rescued his mission from vulgar propaganda. As noted earlier, Grierson and the group of filmmakers around him sought to position their work 'beyond the newsmen and the magazine men and the lecturers [in order to] wander into the world of documentary proper, into the only world in which documentary can hope to achieve the ordinary virtues of an art' (Grierson, 1946, p. 79). The importance of this distancing manoeuvre is that, for Grierson and his group, art represents a different order of reality and truth. Art, so to speak, is its own unarguable propaganda for the higher truths of the human spirit. The problem for post-colonial documentary is the culturally specific, Eurocentric and totalising nature of these 'truths'. Historically, for example, the British documentary movement accommodated itself effortlessly to that nation's later wartime propaganda effort, creating another series of 'classic documentaries' - particularly the Humphrey Jennings oeuvre, such films as Listen to Britain (1942), Fires Were Started (1943), and A Diary for Timothy (1945), among many others (Barnouw 1993: 139-149; Mackenzie 1984).

Partly derived from Russian theorists, then, Griersonian documentary invents a syntax for making meaning and narrative out of actuality footage (Winston 1995; Barnouw 1993). This film grammar that the British docu- 
mentary movement developed over the whole body of its work is readily characterised: arising as a solution to the limitations of contemporary film technology - unblimped 35mm cameras which made synchronised sound recording impossible, heavy and cumbersome equipment, and slow film speeds - the classic Griersonian documentary typically constructs its argument through a highly-crafted 'montage' set to music of silent, staged actuality material. Its narrative is driven by the aptly-named 'voice-of-God' commentary. This particular 'jargon of authenticity', in Paul Arthur's felicitous borrowing from Adorno, in turn authorises meaning and truth; the formal conventions become naturalised as transparent reproduction of reality (Arthur 1993; Adorno 1973). This specific representational style - with its characteristic, authoritatively-voiced, epistemological under-pinnings - is shared by all the work of the movement, whether documentary aspiring to the 'ordinary virtues of an art', or their more humble cousins, the 'newsreels' and 'educationals'. The style becomes 'the classic documentary'. When these formal solutions are transplanted into post-colonial space, however, the mask tends to fall: the bourgeois voice is revealed in all its naked, totalising authoritarianism. Griersonian documentary, shorn of its apologist domestic meanings and disguises, transforms into a rhetoric of empire.

\section{Fiji Day 1971: Things Fall Apart}

Fiji Day 1971 is a ten-minute film of celebrations on the first anniversary of independence. Various activities around regional towns and islands are briefly shown, but the major part of the film covers the climactic ceremonies on October 10 at Albert Park, Suva. Intercut with a remarkable speech by the Prime Minister, are endless scenes of schoolchildren, community groups, and military units marching past an official podium where Government ministers and other dignitaries are seated. Unfortunately, it had rained heavily the day before, and Albert Park became a sea of mud. The crisp white dresses and socks of the school children are splattered; shoes and sandals become sucked off in the mud; march formations begin to collapse as participants jump puddles or pause to retrieve their shoes. Relentlessly, the camera soldiers on minute after minute, recording in unremitting detail the disintegrating spectaclethrough wide-shots of marching formations, mid-shots from the waist up of marchers, and close-ups of feet in the mud, including one startling close-up of an abandoned thong sandal. As a consequence of this film grammar, the spectator is torn between the guilty pleasures of laughter, and respect for the 
participants and their devotion to the solemnity of the occasion.

I argue that such moments of emotional and aesthetic disjunction are classic sites, inevitable dislocations, that occur when an expatriate, Griersonian, documentary logic is transferred to post-colonial space. One traditionally shoots feet as cutaways for the mid shots of marching girls, to enable filmgrammatical editing of the sequence; but, in the mud of Albert Park, this logic becomes relentlessly degrading of the schoolchildren, the ceremony, and indeed Fiji itself. Perhaps Ratu Sir Kamisese Mara rescues the film with his magnificent speech. But I argue that it is this kind of disjunction of images, between mud and oratory, that is the sign of the post-colonial. There are three observations I want to flag here: no Fijian cameraperson would have emphasised the mud (there are technical ways around using the close-ups of muddy feet, dissolves for example); the film strikes me as passionless, distanced, detached from what is, presumably, a highly-charged emotional occasion; and finally, note that the Prime Minister explicitly raises the theme of race relations in his speech:

Social reconciliation will in the end be achieved more by the change of manners than by any revolution of politics. It is how we think of each other, how we talk to each other, and how we relate to each other's authority that will matter most. [...] The change of attitude is the change that will decide the future of our society. (Ratu Sir Kamisese Mara, Fiji Day 1971)

In the 50 or so newsreels I have viewed, this call to unity is the central core of almost all productions. They reflect, clearly, government policy: race is sometimes explicit, other times subtly suggested, but it is always there. But in Government propaganda, that is, the work of the Fiji Film Unit, a positive spin is always presented. We now know the consequences, the reality, behind this fundamental tension. Britain bequeathed not a stable, self-governing polity, but a society fatally divided along racial lines. In another colonial context, that of Hong Kong in the 1960s, Mathew Turner remarks of the work of the similarly founded Hong Kong Film Unit and the Hong Kong Government publicity apparatus:

This is a chocolate box (imagery) with a bitter centre. For the Sixties was also an era of harsh working conditions and grim housing; a raw 
decade of poverty, exploitation, sacrifice and instability. But if Hong Kong people had to 'eat bitterness' during the Sixties, they also chose to consume sugar-coated images of freedom, westernisation, and affluence, laying the foundations for an ambiguous cultural identity (Turner, 1995, p. xv).('Eat bitterness' is a direct translation of a Cantonese term for 'hard times').

This analysis seems to me to resonate strongly with the early work of the Fiji Film Unit, but it is up to contemporary Fijian documentary filmmakers to determine, and reveal, what is the bitter centre here. I suggest that in terms of poverty and hardship there is much in common with the Hong Kong archive, but I also suspect that in Fiji, race relations remain an enduring core and source of bitterness.

\section{The Fiji Film Unit Presents...}

Although newsreel length, Fiji Day 1971 falls into the category of 'prestige films'; it was the major national documentary project of that year, intended for wide internal and external distribution, and (after the public service produced Royal Visit film of 1970), was also the first production under Alan Harkness of the newly created Fiji Film Unit. However, its themes and stylistic apparatus are identical to the numerous news magazines that the Fiji Film Unit began to produce irregularly but roughly on a monthly basis from 1971 to 1984. As an aside, there's a nice irony here: the theatrical exhibition of $16 \mathrm{~mm}$ films - and therefore the whole distribution system of Fiji Film Unit productions - was made possible by the decision of all five Fiji cinemas to install $16 \mathrm{~mm}$ projectors, specifically in order to screen the Muhammad Ali fights, which were airfreighted out a few days after the event. Government propaganda is thus made possible by uniquely Fijian commercial and cultural imperatives.

Over the 15 years of their production, the newsreels go through a series of title and credit permutations, reflecting behind-the-scenes politicking and bureaucratic jockeying for power. Some of these are: 'The Public Relations Office presents...'; a PRO logo positioned above 'The Fiji Film Unit presents...'; end credits also vary, between 'A PRO Production', to 'The Fiji Film Unit, Government of Fiji', and there are no crew credits; about a year after their first appearance they become 'Pictorial Diary'; a few years later they are called 'Fiji News'; and by the early 1980s they have introduced a 
fancy, four box colour split screen. The four images are carefully crafted to reinforce ideas of social and racial harmony: top left is a pile of bags of sugar (representing the economy, presumably); top right is an Indian traditional dance; bottom left is a Fijian traditional dance; and bottom right is a scene of professional boxing (representing who knows what).

Each news magazine covers between three to six stories. Below is a breakdown of the topics covered in 47 editions, in descending order of frequency:

Development/industry/agriculture 31

Politicians'activities 29

Ceremonial activities/official visits 19

Cultural activities $\quad 15$

Social problems 11

Education 9

Natural disasters 5

Foreign (Australian and NZ) aid 5

Sport 5

Two notes: the first two categories tend to be cross-over topics, in that development/industry/agriculture are often treated through the presence of a politician 'opening' a new project. Secondly, the category of Social Problems is without exception treated in terms of fast, efficient Government solution. For example, a dockers' strike in Pictorial Review Number 2 is covered by three or four scenes of idle docks, a derogatory shot of dock workers sitting on the empty wharf playing cards, then a voice-over announcement that the strike was quickly resolved through the direct intervention of the Prime Minister, placed over now busy port scenes.

As this brief summary shows, these 'news magazines' are not documentary in any conventional sense, or even news: they accurately represent the propaganda arm of a Government in transition from colony to post-colonial status. One of the features that stands out over this whole oeuvre is the number of white faces and voices that seem to occupy centre-stage, and in effect run the country; many are indeed Ministers, and if not that, then technocrats and bureaucrats. In fact, they outnumber Fijian faces seated on the official podium in Fiji Day 1971, but tend to thin out as the decade wears on.

\section{Pictorial Review}

Pictorial Review Number 17 (1973) is a typical example of the news magazine genre: black and white, of one-reel (ten minutes) duration, containing 218 PACIFIC JOURNALISM REVIEW 11 (2) 2005 
three disparate items or stories entitled, respectively, 'The Queen's Unofficial Visit', 'Opening of the Great Council of Chiefs', and 'The Dance Theatre of Fiji'. To reiterate my argument: this news magazine strikes me as demonstrating yet again the strange slippages, incongruities, disjunctions, that occur when a metropolitan art form, from another era and social context entirely, is transferred to post-colonial space. The first false note is the opening image of a woman banging on a traditional log drum; this comes from an earlier film and an unrelated occasion. It is inserted here to 'stand for' Fiji, to add a touch of the exotic, to provide a memento for the Queen's entourage, who will take a copy of the film back to London, and to titillate metropolitan audiences. After this opening image, the film shows a series of informal royal activities: descending the steps of the aircraft, greetings on the tarmac, inspecting a troop of Fijian soldiers, a motorcade through semi-deserted streets. Because the visit is 'unofficial' - the Queen is stopping off on her way to Sydney to open the Opera House - the Fiji Film Unit camera appears to have been kept at a distance from the royal party, and in essence to have been forced to construct a minor news item from hastily filmed 'grabs' of actuality.

The result is a whole series of further false notes: one that stands out is the scene - all in long shots and jumpcuts - of the Queen in a summer dress wandering around on her own taking photographs of the traditional ceremonial house recently built for her representative in Fiji, the Governor General. Elizabeth the Second is, after all, Queen of Fiji, yet here she transmutes through the Griersonian documentary form into just another white tourist, taking 'happy snaps' for the family album - Her Majesty without majesty. But clearly, the most glaring disjunction is the positioning of the first and second items so that each comments on the other within the magazine structure: the setting side-by-side of the Great (white) Chief and the Great Council of (black) Chiefs. While the first item, for whatever reason, emphasises an ordinary young woman stripped of all royal trappings, the second is imbued with high ceremony and dignity; the incoherent, snapshot images of the Queen lack filmic authority, whereas the Chiefs are shot in long, static images from a low angle, in a way that emphasises gravitas and long-standing sovereignty. Whether intentional or unthinking, this extraordinary juxtaposition is startling in its incongruity, its strangeness, its uncanniness, its schizophrenia.

Theorising from an Indian coloniality that is historically both more distant and more brutal than Fiji's, Homi Bhabha explores mimicry and mockery as responses to the colonial condition. He views them primarily in a nega- 
tive light: central to colonial subjectivity, they act as mechanisms for social control which attack the integrity of both coloniser and colonised. Yet he notes: 'The epic intention of the civilizing mission (...) often produces a text rich in trompe-l'oeil, irony, mimicry and repetition' (Bhabha, 1994, p. 85). When the same effects are regarded as a positive response to colonial power, however, they provide a suggestive reading for post-colonial spectatorship and documentary:

The 'unthought' across which colonial man is articulated (...) results in the splitting of colonial discourse so that two attitudes persist; one takes reality into consideration while the other disavows it and replaces it by a product of desire that repeats, re-articulates 'reality' as mimicry. (p. 91, original emphasis)

Setting the newsreel in this context begins to bring home the full force of the insight into colonial subjectivity that Bhabha's ideas of 'mimicry', 'mockery', and 'sly civility' provide:

It is from this area between mimicry and mockery, where the reforming, civilising mission is threatened by the displacing gaze of its disciplinary double, that my instances of colonial imitation come. What they all share is a discursive process by which excess or slippage produced by the ambivalence of mimicry (almost the same, but not quite) does not merely rupture the discourse, but becomes transformed into an uncertainty which fixes the colonial subject as a 'partial' presence. By 'partial' I mean both incomplete and 'virtual'. (pp. 85-86, original emphasis)

Juxtaposing mud and oratory, white and black chiefs, are evidence of just such excess and slippage in the work of expatriate film-makers; documentary, a 'discourse of sobriety' in Nichols's characterisation, is ruptured by unintended, sly humour, by 'native' mimicry of metropolitan form and formality, by the representation of inscrutable and incomplete post-colonial subjectivities and social actors (Nichols, 1991).

Finally in this particular news magazine, linked through the idea of the opening of the Sydney Opera House, the end purpose of the Queen's visit to Fiji, is the item on a Fijian dance troupe, which is rehearsing in preparation for representing Fijian culture at the Opera House ceremonies. By 1973, 
then, Indian culture has been neatly disappeared from ideas of Fijian identity. What Ratu Sir Kamisese Mara in 1971 called 'peace, harmony, tolerance and goodwill in Fiji' appears to be already under pressure in government propaganda. In post-colonial space, the Griersonian form begins to show signs of strain, of incongruity, of anachronism — out of place, and out of time.

\section{'My Greatest Mistake'-Alan Harkness}

By 1975, pressure was mounting in Fiji for the 'localising' of much of government, and other arenas. Alan Harkness's contract was not renewed, to his great regret. He remarked: 'I feel I never achieved the vision I had for the Fiji Film Unit' (Harkness 2004). He also claimed that the Unit collapsed after his departure, but the archive tells a different story. He also explicitly defined his mission, as he saw it, as twofold: to make films that were 'good for the Government', and to make films that were 'good for the people'. The former suggests a pragmatic strategy for political survival; but the latter smacks of colonialist hubris, 'white man's burden' and all that. My own view is that it would be wrong to characterise Harkness in these terms: he comes across as a good-natured, fair-go, non-racist Australian professional filmmaker; in this cross-cultural context, however, he is an innocent abroad.

For example, it is interesting that he saved to the final minutes of my interview with him his deepest feeling and regret about his whole experience in Fiji, and what he said is to his credit:

My greatest mistake was dealing with expatriate civil servants, and not talking directly to Cabinet. I drew up a five year plan for the Unit before I even arrived, and assumed it had gone to Cabinet, but I discovered by chance a decade later that the Prime Minister and other Ministers had never seen the document. It had only gone as far as Hackett and Wormsley [British expatriate civil servants], who retired within a year or two of my arrival. So all the time I thought everybody was on the same plan, but they [the politicians] never saw it (Harkness, 2004).

Harkness felt he was fighting blindfold against unseen enemies throughout his time in Fiji. Yet the Fiji Film Unit was to continue importing expatriate filmmakers, among them Ian Weddell and John Van Den Berg (Weddell, 2005). Like the Griersonian hierarchy of documentary, colonialism maps another powerful structure on to the production apparatus, and this hierarchy is col- 
oured by ideologies of race. I would argue - along with Homi Bhaba - that much of the work that results constructs a curiously distanced, schizophrenic relationship to its audience, a structural contradiction that is particularly glaring for local audiences. The Fiji Film Unit's attempt to address simultaneously metropolitan, overseas, and local markets (the latter, disempowered post-colonial subjects of Empire), and to deploy moreover a formal vocabulary that constructs an ideal, unitary Griersonian audience of concerned democratic citizenry, often produces documentary with a confused 'voice', to use Bill Nichols' terminology (Nichols, 1988). Not only is cross-cultural communication not theorised, but local conditions are not even researched. It is simply assumed that what works in Britain will work in the Colony; a discourse - in Foucault's sense comprising both texts and their means of delivery - designed for a citizenry in a sophisticated and long-standing democracy is mapped on to a very different polity and demographic: a poor, divided populace in a newly independent colony. The whole Griersonian apparatus is then deployed — even to the same, hopeless search for a distribution and exhibition structure that offers an alternative to privately-owned cinema circuits, such as travelling film shows with portable projectors which visit outlying communities and village halls - yet the local audience is not that of Grierson's essentially conservative, Calvinist project: neither a working class to be soothed with visions of class harmony, nor a middle class to be educated into its imperial responsibilities. All films produced by the Fiji Film Unit were released only in English; Fijian or Hindi versions were never made-I rest my case.

\section{Conclusion: The Archive}

As Edward Said reminds us, the actual work of European Empire is underpinned by a massive textualising apparatus that both enables, and is in turn generated by it (Said, 1978, 1994). This colonial discourse assumes certain common features whether deployed in Africa, India, or the Pacific, and its textual apparatus encompasses not only literary work, travellers' tales, journalism, colonial administrators' memoirs, and so on, but also the logocentric institutions of law, religion, and education (Spurr, 1993). But if the shock arrival of the word may be said to suddenly, radically, and forever change the pre-colonial world, the impact of the camera and its Western discourse of photographic images was at least as traumatic. Fiji is not unique in having been subjected to this powerful discourse; what is remarkable about Fiji, how- 
ever, is that the colonial apparatus extended at full vitality for so long, into the nation's very recent past. Contemporary film-makers must deal with a documentary archive that dates only from the 1970s, an archive which consists, virtually without exception, of the work of the propaganda arm of postcolonial Government, the Fiji Film Unit. This study explored this body of work, and interrogated the documentary tradition that produced it. Taken together, they represent the documentary film culture that is in place at the moment when post-colonial imperatives begin to act on local film-makers, the material and theoretical base from which any post-colonial documentary project must launch itself.

So I want to end on a caveat, and an appeal. Over time, documentary film tends to acquire an added aura of dignity, authenticity, gravitas - particularly if it presents in black and white, with markers of age such as scratches and faded emulsion. Yet, as I hope I have shown, there are many factors acting against documentary authenticity which came into play in the early work of the Fiji Film Unit — careful staging and re-enactment, propaganda agendas, lack of cross-cultural sensitivity and knowledge, inappropriate modes of address to untheorised audiences - and its archive must thus be read with great care. These films are the highly crafted work of a sophisticated government propaganda apparatus, and constructed moreover in the main through expatriate eyes. Some of the tasks of the contemporary, and next, generations of Fijian film-makers must be to read the archive subversively, 'against the grain'; to 'write back' to it; to construct their own documentary history for Fiji.

But before that can happen, the archive must be rescued. And here is my final appeal: I found the Fiji Film Unit archive scattered over several sites, uncatalogued, shelved in humid basements in rusty metal cans and brittle plastic boxes. I even discovered the ruins of the $16 \mathrm{~mm}$ editing machine and Nagra recorder that Alan Harkness used almost 35 years ago. To readers here, wherever they may be located - government members, public servants, students, teachers - I appeal for you to start a film preservation movement, agitate for a national film archive, take to the streets: 'A country without documentaries is like a family without a photo album' (Chilean film-maker Patricio Guzman, cited on Australian Film, Television and Radio School website). To lose the Fijian documentary archive would be a national tragedy.

\section{Postscript}

The Fiji Film Unit was fully localised by 1985, but in that year underwent a 
series of convulsions as it passed into the hands of an NGO, a German media Foundation. Since then it has undergone a series of name changes, but today - as the Fiji Film and Television Unit — produces from its fully digital facilities an hour and a half of television each week in three languages, Hindi, Fijian and English, no mean feat for its small, highly-professional, 16 member team. However, in terms of content, news agenda, and documentary style, its propaganda mission remains much the same.

\section{Note}

${ }^{1}$ See the author's Ghostwriting Hongkong, forthcoming.

\section{References}

Adorno, T. H. (1973). The jargon of authenticity. Evanston, Ill.: Northwestern University Press.

Arthur, P. (1993). Jargons of authenticity: Three American moments. In Renov M. (Ed.), Theorizing documentary. New York: Routledge.

Barnouw, E. (1993). Documentary: A history of the non-fiction film. (2nd Ed.). Oxford: Oxford University Press.

Bhabha, H. (1994). Of mimicry and man. In The location of culture. London: Routledge. Constantine, S. (1986). Bringing the empire alive. In Mackenzie, J.M. (Ed.), Imperialism and popular culture. Manchester: Manchester University Press.

Grierson, J. (1946). Cited in Hardy F. (Ed.), Grierson on documentary. London: Collins. Harkness, A. (2004). Taped interview with the author, 27 September 2004.

Mackenzie, J.M., (1984). Propaganda and empire. Manchester: Manchester University Press.

Moran, A. (1991). Projecting Australia: Government film since 1945. Sydney: Currency Press.

Murray, J.L. (1958). Government publicity in Hong Kong: A report by the public relations officer (J.L.Murray). Hong Kong: Hong Kong Collection, University of Hong Kong Library.

Nichols, B., (1988). The voice of documentary In Rosenthal A. (Ed.), New challenges for documentary. Berkeley: University of California Press.

Nichols, B. (1991). Representing reality. Bloomington: Indiana University Press.

Paget, D. (1990). True Stories? Documentary drama on radio, screen and stage. Manchester: Manchester University Press.

Said, E.W., (1978). Orientalism. London: Routledge and Kegan Paul.

Said, E.W. (1994). Culture and imperialism. London: Vintage.

Spurr, D., (1993). The rhetoric of empire: Colonial discourse in journalism, travel writing, and imperial administration. Durham,N.C: Duke University Press.

Weddell, I. (2005). Taped interview with the author, 5 January 2005.

Winston, B. (1995). Claiming the real: The documentary film revisited. London: British Film Institute. 


\section{Filmography}

Diary For Timothy, Humphrey Jennings, 1945

Drifters, John Grierson, 1929

Fiji Day 1971, Alan Harkness, 1971

Fires Were Started, Humphrey Jennings, 1943

Housing Problems, Arthur Elton and Edgar Anstey, 1935

Industrial Britain, Robert Flaherty and John Grierson, 1933

Listen To Britain, Humphrey Jennings, 1942

Night Mail, Harry Watt and Basil Wright, 1936

Pictorial Review Number 2, Alan Harkness, 1972

Pictorial Review Number 17, Alan Harkness, 1973

Song of Ceylon, Basil Wright, 1934

Dr Philip Robertson is a Senior Lecturer in Film Studies at Central Queensland University, Rockhampton, Queensland. An earlier version of this paper was presented at the Journalism Education Association (JEA) conference at Suva, Fiji, 3-8 December 2004.

p.robertson@cqu.edu.au

Documentary Cinematheque: ejournalism.au.com/philsite/home4.html

\section{Pacific}

Journalism Refiew

\section{Pacific Journalism Review back copies}

Back copies of Pacific Journalism Review can be ordered from:

South Pacific Books NZ Ltd www.southpacificbooks.co.nz USP Book Centre www.uspbookcentre.com

PJR subscription details and order forms are online at: www.pjreview.info 